\title{
KASUS KEMATIAN AKIBAT DICHLORVOS DAN PHENTHOAT
}

\author{
Putu Nandya Nandita, Ni Made Widi Astuti, Pande Made Nova Armita Sari, IMA \\ Gelgel Wirasuta \\ Departemen Toksikolgi Forensik \\ Laboratorium Toksikologi Forensik Universitas Udayana \\ Program Studi Farmasi Fakultas Matematika dan Ilmu Pengetahuan Alam \\ Universitas Udayana Denpasar Bali Indonesia \\ *email : nindynandya5@gmail.com
}

\begin{abstract}
Dichlorvos and phenthoat are organophosphate group pesticides which have toxic effects on humans and can cause fatal deaths. Suicide cases using organophosphate pesticides (dichlorvos and phenthoat) are one of the postmortem toxicology analysis studies. As a forensic toxicologist, competency is needed to be able to handle suicide deaths that are thought to be caused by dichlorvos and phenthoat. Handling suicides due to dichlorvos and phenthoate is done from sample preparation, screening tests, assurance tests, determination, and data interpretation. Forensic toxicology analysis in the case showed that high concentrations of dichlorvos and phenthoate were found to have toxic effects on the victim's body. Based on the toxicological analysis, it can be concluded that it is true that the victim died from organophosphate poisoning (dichlorvos and phenthoat).
\end{abstract}

Keywords: Diclorvost, Phentoate, Postmortem Toxicology

\section{PENDAHULUAN}

Pestisida adalah zat untuk membunuh dan mengendalikan hama. Penggunaan pestisidan yang tidak tepat dapat mengakibatkan keracunan bahkan kematian. Organisasi Kesehatan Dunia (WHO) memperkirakan setiap tahun terjadi sekitar 25 juta kasus keracunan pestisida atau sekitar 68.493 kasus setiap hari [1]. Di negara-negara yang belum berkembang, terdapat lebih dari $60 \%$ kasus kematian akibat pestisida [2]. Data dari WHO juga menunjukkan bahwa telah terjadi 220.000 kasus kematian bunuh diri menggunakan pestisida [1]. Beberapa penelitian terhadap kematian oleh pestisida memperkirakan bahwa 330.000 orang meninggal oleh asupan pestisida yang disengaja [2].
Organofosfat merupakan zat kimia yang terkandung pada pestisida untuk membunuh hama. Organofosfat juga digunakan dalam produk rumah tangga, seperti pembasmi nyamuk, kecoa, dan hewan pengganggu lainnya. Dichlorvos dan phenthoat adalah pestisida golongan organofosfat yang umum digunakan di seluruh dunia, namun senyawa tersebut juga memiliki efek toksik pada manusia [3]. Pada manusia organofosfat menyebabkan sakit kepala, pusing, malaise, mual, miosis, dan kelemahan otot. Organofosfat tersedia secara komersial sebagai insektisida dalam bidang pertanian. Kematian akibat organofosfat sering terjadi pada manusia melalui paparan yang tidak disengaja melewati kulit dan saluran nafas selama proses agrikultur. Selain itu, kematian 
akibat organofosfat juga terjadi karena penggunaan yang disengaja untuk bunuh diri.

$$
\text { Pemeriksaan senyawa }
$$

dichlorvos dan phenthoat di laboratorium pengujian memerlukan metode yang cukup teruji dengan hasil yang optimal. Pada kasus kematian oleh dichlorvos dan phenthoat, sampel biologis yang digunakan bervariasi tergantung dari kebutuhan pemeriksaan. Penelitian terkait distribusi organofosfat dalam kasus kematian telah banyak dilakukan. Konsentrasi organofosfat dalam berbagai cairan tubuh dan jaringan dapat membantu menentukan spesimen yang dipilih dalam pengujian dengan analisis toksikologi postmortem [4]. Sampel yang berupa spesimen biologis memerlukan perlakuan khusus untuk mendapatkan hasil analisis yang optimal. Sebagai seorang toksikolog forensik, diperlukan suatu kompetensi untuk dapat menangani kasus kematian akibat bunuh diri yang diduga disebabkan oleh dichlorvos dan phenthoat.

\section{KASUS KEMATIAN AKIBAT KERACUNAN DICHLORVOS DAN PHENTHOAT}

Keracunan

pestisida organofosfat adalah masalah utama kesehatan di seluruh dunia. Keracunan pestisida tersebut sangat mempengaruhi masalah kesehatan dunia dengan tingkat kematian yang tinggi. Ribuan orang meninggal setiap tahun akibat keracunan pestisida organofosfat, terutama di wilayah Asia Pasifik. Di negara- negara yang belum berkembang, terdapat lebih dari $60 \%$ kasus kematian akibat pestisida [2]. Beberapa penelitian melaporkan kasus-kasus kematian oleh pestisida di Cina, Malaysia, Sri Lanka, dan Trinidad-To-bago,dan

memperkirakan bahwa 330.000 orang meninggal karena asupan pestisida yang disengaja. Sedangkan di Indonesia diperkirakan sekitar 12.000 kasus kematian setiap tahunnya diakibatkan oleh keracunan pestisida akut [10].

Dichlorvos dan phenthoate merupakan pestisida golongan organofosfat. Terdapat beberapa kasus forensik penggunaan dichlorvos dan phenthoate yang menimbulkan keracunan bahkan kematian. Salah satu kasus bunuh diri dengan dichlorvos dan phenthoate yaitu pada seorang pria berusia sekitar 80 tahun di Tokyo Jepang. Pria tersebut ditemukan tidak sadarkan diri di kamarnya dengan catatan bunuh diri dan botol berisi cairan kecoklatan gelap yang terdiri dari dichlorvos dan phenthoat. Pria tersebut kemudian diautopsi setelah 17 jam kematian. Saat autopsi dilakukan pemeriksaan luar dan pemeriksaan dalam pada tubuh korban. Hasil pengujian analisis toksikologi forensik menunjukkan bahwa korban telah terpapar dichlorvos dengan konsentrasi yang cukup untuk menimbulkan efek kematian pada korban dan phenthoate yang dicerna. Berdasarkan kasus kematian akibat dichlorvos yang pernah dilaporkan, konsentrasi dichlorvos pada darah

52 Putu Nandya Nandita, Ni Made Widi Astuti, Pande Made Nova Armita Sari, IMA Gelgel Wirasuta Departemen Toksikolgi Forensik, Laboratorium Toksikologi Forensik Universitas Udayana Program Studi Farmasi Fakultas Matematika dan Ilmu Pengetahuan Alam Universitas Udayana Bali Indonesia 
korban setelah 24 jam yakni $29 \mu \mathrm{g} / \mathrm{mL}$. Laporan kasus lainnya menunjukkan konsentrasi dichlorvos setelah 3 hari kematian yakni 4,4 $\mu \mathrm{g} / \mathrm{mL}$ [4]. Untuk kasus kematian bunuh diri akibat phentoate yang pernah dilaporkan, konsentrasi phenthoate dalam darah seesar 18,5 $\mathrm{mg} / \mathrm{mL}$ [4].

\section{EFEK}

DICHLORVOS

PHENTHOAT

\section{KERACUNAN}

DAN

Dichlorvos dan phenthoat adalah pestisida golongan organofosfat. Organofosfat bekerja dengan menghambat asetilkolinesterase sehingga terjadi akumulasi asetilkolin pada sinapsis kolinergik yang menyebabkan rangsangan berlebih pada reseptor muskarinik dan nikotinik [4]. Organofosfat dapat menimbulkan keracunan karena menghambat enzim kolinesterase. Enzim ini berfungsi menghidrolisis asetilkolin menjadi asetat dan kolin. Organofosfat mampu menghambat kerja enzim kolinesterase karena berikatan dengan sisi aktif enzim. Asetilkolin berperan penting pada sistem saraf autonomi yang mengatur kerja pupil mata, jantung, dan pembuluh darah [4].

Keracunan organofosfat dapat terjadi melalui kulit, mata, mulut jika tertelan, dan hidung jika terhirup dengan dosis berlebih. Gejala keracunan organofosfat timbul 6-12 jam setelah paparan. Gejala awal adalah ruam dan iritasi kulit, mual, muntah, lemas, sakit kepala, dan gangguan penglihatan. Gejala lanjutan seperti keluar ludah berlebih, keluar lender dari hidung, berkemih berlebih, diare, keringat berlebih, air mata berlebih, kelemahan yang disertai sesak nafas, kelumpuhan otot rangka, sukar bicara, hilangnya reflek, kejang, dan koma [7].

Dichlorvos termasuk ke dalam pestisida kelas $\mathrm{Ib}$ yaitu berbahaya. Dichlorvos cepat dimetabolisme dan dieliminasi dari tubuh melalui udara dan urin. Metabolit yang umum ditemukan adalah dimethylphosphate dan dichloroacetaldehyde. Dosis letal oral yang telah dilaporkan yaitu 400 $\mathrm{mg} / \mathrm{kgBB}$ dan dosis toksik 300 $\mathrm{mg} / \mathrm{kg}$. Waktu paruh dichlorvos 25 menit [4]. Phenthoate termasuk ke dalam pestisida kelas Ia yaitu sangat berbahaya [4]. Phenthoate cepat diabsorpsi melalui membran mukus sistem pencernaan, sistem respirasi, dan kulit. Rute utama eliminasi phenthoate adalah melalui ginjal [7]. Metabolit utama dari phenthoate adalah asam phenthoate dan demethyl phenthoate oxon acid [8].

\section{ANALISIS TOKSIKOLOGI FORENSIK KASUS KEMATIAN AKIBAT DICHLORVOS DAN PHENTHOAT}

Secara umum tugas analisis toksikolog forensik dapat dikelompokkan ke dalam tiga tahap yaitu penyiapan sampel, uji penapisan "screening test", uji konfirmasi yang meliputi uji identifikasi dan kuantifikasi, interpretasi temuan analisis, dan penulisan laporan analisis [9]. Sampel dari toksikologi forensik

53 Putu Nandya Nandita, Ni Made Widi Astuti, Pande Made Nova Armita Sari, IMA Gelgel Wirasuta Departemen Toksikolgi Forensik, Laboratorium Toksikologi Forensik Universitas Udayana Program Studi Farmasi Fakultas Matematika dan Ilmu Pengetahuan Alam Universitas Udayana Bali Indonesia 
pada umumnya adalah spesimen biologi seperti cairan biologis (darah, urin, air ludah), jaringan biologis atau organ tubuh. Preparasi sampel adalah salah satu faktor penentu keberhasilan analisis toksikologi forensik disamping kehandalan penguasaan metode analisis instrumentasi. Berbeda dengan analisis kimia lainnya, hasil indentifikasi dan kuantifikasi dari analit bukan merupakan tujuan akhir dari analisis toksikologi forensik. Seorang toksikolog forensik dituntut harus mampu menerjemahkan apakah analit (toksikan) yang diketemukan dengan kadar tertentu dapat dikatakan sebagai penyebab kematian [9]. Kasus kematian akibat keracunan diclorvost dan phentoate merupakan bagian dari postmortem toxicology. Toksikologi postmortem digunakan untuk mendeteksi adanya alkohol atau obat-obatan yang menyebabkan atau berkontribusi terhadap kematian seseorang. Adapun tahapan analisis postmortem toxicology adalah sebagai berikut.

a. Penyiapan Sampel

Beberapa hal yang perlu diperhitungkan dalam tahapan penyiapan sampel adalah jenis dan sifat biologis spesimen, fisikokimia dari spesimen, serta tujuan analisis. Dengan demikian akan dapat merancang atau memilih metode penanganan sampel, jumlah sampel yang akan digunakan, serta memilih metode analisis yang tepat. Penanganan sampel perlu mendapat perhatian khusus, karena sebagian besar sampel adalah materi biologis, sehingga sedapat mungkin mencegah terjadinya penguraian dari analit [9].

b. Uji Penapisan atau Screening Test

Toksikologi postmortem biasanya diawali dengan uji skrining obat. Uji skrining dapat dilakukan dengan "general unknown test" (pendekatan terbuka) dan dengan pendekatan yang ditargetkan. Pendekatan terbuka dengan "general unknown test" dilakukan apabila berdasarkan deskripsi kasus tidak didapatkan senyawa spesifik yang menjadi target. Pendekatan yang ditargetkan dilakukan apabila berdasarkan deskripsi kasus ditemukan senyawa spesifik yang menjadi target [4].

c. Uji Pemastian atau Confirmatory Test

Uji pemastian bertujuan untuk memastikan identitas analit. Meningkatnya derajat spesifisitas pada uji ini akan sangat memungkinkan mengenali identitas analit, sehingga dapat menentukan secara spesifik toksikan yang ada. Hasil uji pemastian (confirmatory test) dapat dijadikan dasar untuk memastikan atau menarik kesimpulan apakah sesorang telah menggunakan obat terlarang atau bahan kimia yang dituduhkan [9].

d. Determinasi dan Interpretasi Temuan Analisis

Uji determinasi bertujuan untuk mengetahui konsentrasi dari senyawa yang telah dipastikan sebelumnya. Temuan analisis sendiri tidak mempunyai makna yang berarti jika tidak dijelaskan makna dari temuan tersebut. Seorang toksikolog 
forensik berkewajiban menerjemahkan temuan tersebut berdasarkan kepakarannya ke dalam suatu kalimat atau laporan, yang dapat menjelaskan atau mampu menjawab pertanyaan yang muncul berkaitan dengan permasalahan atau kasus yang dituduhkan. Data temuan hasil uji penapisan dapat dijadikan petunjuk bukan untuk menarik kesimpulan bahwa seseorang telah terpapar atau menggunakan obat terlarang [9].

$$
\text { Analisis toksikologi }
$$

postmortem dilakukan pada salah satu kasus bunuh diri dengan dichlorvos dan phenthoate pada seorang pria berusia sekitar 80 tahun. Pada kasus tersebut diawali dengan uji skrining obat dengan menggunakan prinsip immunochemical drug screening kit Triage DOA [3]. Triage DOA (drug of abuse) adalah salah satu immunoassay yang digunakan untuk penentuan kualitatif dari metabolit utama obat-obatan terlarang seperti Benzodiazepin, Kokain, Amfetamin atau Metamfetamin, Metadon, Tetrahidrocannabinol, Opiat, Barbiturat, dan Antidepresan Tricyclic dalam urin. Dalam penelitian ini uji skrining menggunakan immunochemical drug screening kit Triage DOA memberikan hasil negatif. Sehingga dapat diketahui bahwa kasus kematian tersebut tidak disebabkan oleh obat-obatan terlarang.

Pada deskripsi kasus dijelaskan bahwa polisi menemukan barang bukti berupa botol yang berisi cairan kecoklatan gelap yang terdiri dari dichlorvos dan phenthoate. Berdasarkan hal tersebut, maka dilakukan pengujian skrining obat dengan pendekatan yang ditargetkan. Untuk mengetahui secara pasti senyawa yang menjadi tersangka pada kasus kematian ini, dilakukan pula pemeriksaan secara internal terhadap korban. Hasil dari pemeriksaan secara internal pada kasus kematian ini yaitu darah jantung berwarna merah kehitaman, mukosa esofagus didenaturasi menjadi warna kecoklatan dan kehilangan elastisitas, serta di dalam lambung ditemukan cairan berlumpur coklat dengan bau yang mudah menguap [3]. Hasil pemeriksaan internal menunjukkan ciri-ciri tubuh terpapar oleh adanya senyawa dichlorvos dan phenthoate.

Selanjutnya dilakukan uji konfirmasi atau uji pemastian untuk memastikan identitas analit yang terlibat dalam kasus kematian yang telah dilaporkan. Uji pemastian dari kasus tersebut menggunakan teknik HPLC-MS [4]. Pada kasus ini sampel yang akan dianalisis dari hasil autopsi adalah sampel darah, urine, dan cairan pencernaan [3]. Berdasarkan hasil uji skrining dan konfirmasi pada spesimen sampel, didapatkan adanya kedua senyawa tersebut pada sampel darah, urin, dan cairan pencernaan. Pada tahap determinasi dan interpretasi hasil, maka data hasil kuantifikasi senyawa target dikaitkan dengan deskripsi kasus untuk dapat menarik kesimpulan.

Hasil dari analisis kantitatif menggunakan metode HPLC-MS, 
secara spesifik menunjukkan konsentrasi dichlorvos yang cukup tinggi. Berdasarkan hasil tersebut, dibandingkan dengan data kematian yang pernah dilaporkan sebelumnya tentang kematian yang diakibatkan oleh diclorovos dan pentoate. Berdasarkan kasus kematian akibat dichlorvos yang pernah dilaporkan, konsentrasi dichlorvos pada darah korban setelah 24 jam yakni 29 $\mu \mathrm{g} / \mathrm{mL}$. Laporan kasus lainnya menunjukkan konsentrasi dichlorvos setelah 3 hari kematian yakni 4,4 $\mu \mathrm{g} / \mathrm{mL}$. Apabila dibandingkan dengan hasil determinasi senyawa dichlorvos pada sampel organ tubuh korban yaitu didapatkan konsentrasi dichlorvos sebesar $11,6 \mu \mathrm{g} / \mathrm{mL}$ pada kapasitas jantung kiri, 4,6 $\mu \mathrm{g} / \mathrm{mL}$ pada kapasitas jantung kanan, 2,54 $\mu \mathrm{g} / \mathrm{mL}$ pada urne, dan 7,35 gram pada isi perut. Hasil tersebut menunjukkan bahwa memang benar korban telah terpapar dichlorvos, dilihat dari distribusi senyawa tersebut disemua jalur metabolisme tubuh. Selain itu, konsentrasi dichlorvos yang didapat cukup untuk menimbulkan efek kematian pada korban [3].

Hasil determinasi dichlorvos juga diperkuat dengan tanda-tanda lain pada tubuh korban yang menguatkan dugaan bahwa kematian korban diakibatkan karena overdosis terhadap dichlorvos. Presentasi klinis overdosis organofosfat termasuk ulkus hemoragik pada saluran pencernaan bagian atas atau perforasi usus kecil pada pasien. Pada kasus bunuh diri yang fatal akibat dichlorvos, ulkus berdarah dari saluran pencernaan atau petechial hemorrhages hingga mukosa lambung. Keseluruhan gejala tersebut ditemukan pada korban saat otopsi [3].

Sementara untuk kasus kematian bunuh diri akibat phentoate yang pernah dilaporkan, konsentrasi phenthoate dalam darah seesar 18,5 $\mathrm{mg} / \mathrm{mL}$, jumlah tersebut jauh lebih tinggi dari yang terdeteksi dalam darah jantung dalam kasus ini. Namun, tidak diketahui secara detail apakah sampel darah postmortem yang diperiksa dalam kasus tersebut merupakan sampel darah perifer atau jantung dalam otopsi. Menimbang bahwa hanya ada satu laporan kasus seperti itu dalam kedokteran forensik, sehingga sulit untuk mengevaluasi konsentrasi senyawa mematikan dari phenthoate dalam darah postmortem [3]. Oleh karena pada kasus ini ditemukan kadar phenthoate dalam perut korban sebesar 4,55 gram, maka dapat disimpulkan bahwa phenthoate telah dicerna. Selain itu, phenthoate mengandung bagian carboxyester di sisi rantai asam yang dihidrolisis oleh karboksilesterase dalam tubuh untuk membentuk metabolit beracun yang tidak sesuai yaitu asam fentoat. Tingkat sisa phenthoate dalam darah manusia yang mengandung dichlorvos secara signifikan lebih tinggi daripada di dalam darah tanpa dichlorvos, hal ini dikarenakan hidrolisis karboktor dalam fenthoat tertunda karena penghambatan aktivitas karboksilesterase oleh dichlorvos, yang menyebabkan kematian yang fatal.

56 Putu Nandya Nandita, Ni Made Widi Astuti, Pande Made Nova Armita Sari, IMA Gelgel Wirasuta Departemen Toksikolgi Forensik, Laboratorium Toksikologi Forensik Universitas Udayana Program Studi Farmasi Fakultas Matematika dan Ilmu Pengetahuan Alam Universitas Udayana Bali Indonesia 


\section{KESIMPULAN}

Dichlorvos dan phenthoat adalah pestisida golongan organofosfat yang memiliki efek toksik pada manusia dan dapat menyebabkan kematian yang fatal. Kasus bunuh diri menggunakan pestisida golongan organofosfat (dichlorvos dan phenthoat) merupakan salah satu kajian analisi toksikologi postmortem. Sebagai seorang toksikolog forensik, diperlukan suatu kompetensi untuk dapat menangani kasus kematian bunuh diri yang diduga disebabkan oleh dichlorvos dan phenthoat. Penanganan kasus bunuh diri akibat dichlorvos dan phenthoate dilakukan dari penyiapan sampel, uji penapisan, uji pemastian, determinasi, dan interpretasi data. Pada penyiapan sampel diperhitungkan jenis dan sifat biologis spesimen, fisikokimia dari spesimen, serta tujuan analisis. Uji skrining pada kasus dilakukan dengan pendekatan yang ditargetkan berdasarkan bukti yang ditemukan berupa botol yang berisi dichlorvos dan phenthoat. Uji pemastian dilakukan untuk mengenali identitas analit, sehingga dapat menentukan secara spesifik toksikan yang ada. Uji determinasi bertujuan untuk mengetahui konsentrasi dari senyawa yang telah dipastikan sebelumnya. Analisis kantitatif menggunakan metode HPLC-MS secara spesifik menunjukkan konsentrasi dichlorvos yang cukup tinggi. Hasil determinasi dichlorvos juga diperkuat dengan tanda-tanda lain pada tubuh korban yang menguatkan dugaan bahwa kematian korban diakibatkan karena overdosis terhadap dichlorvos. Hasil determinasi juga ditemukan kadar phenthoate dalam perut korban sehingga disimpulkan bahwa phenthoate telah dicerna. Phenthoate membentuk metabolit beracun yang tidak sesuai yaitu asam fentoat yang menyebabkan kematian yang fatal. Berdasarkan analisis toksikologi tersebut, maka dapat disimpulkan bahwa memang benar korban meninggal akibat keracunan pestisida golongan organofosfat (dichlorvos dan phenthoat)

\section{DAFTAR PUSTAKA}

[1]. World Health Organization. 2004. World Health Report 2004. Geneva: World Health Organization.

[2]. Lee M. S., Kerns E. H.. 1999. LC/MS Applications In Drugs Development. Mass Spectrometry Reviews. Vol.18 (3): 187-279.

[3]. Nara, A., C. Yamada, T. Kodama, K. Saka, dan T. Takagi. 2018. Fatal Poisoning with Both Dichlorvos and Phenthoate. Journal of Forensic Sciences: 1-4.

[4]. Moffat, A. C., M. D. Osselton and B. Widdop. 2005. Clarke's Analysis of Drugs and Poisons. Pharmaceutical Press.

[5]. Shimizu K et al. 1996. Tissue distribution of DDVP after fatal ingestion. Forensic Sci Int 83:61-66.

[6]. Abe E et al. 2008. A fatal dichlorvos poisoning:

57 Putu Nandya Nandita, Ni Made Widi Astuti, Pande Made Nova Armita Sari, IMA Gelgel Wirasuta Departemen Toksikolgi Forensik, Laboratorium Toksikologi Forensik Universitas Udayana Program Studi Farmasi Fakultas Matematika dan Ilmu Pengetahuan Alam Universitas Udayana 
concentrations in biological specimens. J Forensic Sci 53: 997-1000.

[7]. Morgan, D.P. 1982. Recognition and Management of Pesticide Poisonings. Washington: U.S. Government Printing Office.

[8]. Kawabata, S., Hayasaka M., Hayashi H., Sakata M., Hatakeyama Y., dan Ogura N. 1994. Phenthoate metabolites in human poisoning. Journal of toxicology.

toxicology. 32 (1): 49-60.

[9]. Wirasuta, I M. A. G. 2008. Analisis Toksikologi Forensik dan Interpretasi Temuan Analisis. Indonesian Journal of Legal and Forensic Sciences, Vol. 1(1).

[10] PANAP. 2013. Kasus Keracunan Pestisida. Diakses $5 \quad$ Maret 2019 http://www.who.imt/mental_he alth/prevention/suicede/pestici des. 